\title{
The relationship between human resource development factors, career growth and turnover intention: The mediating role of organizational commitment
}

\author{
Muhammad Shahid Nawaz* and Faizuniah Pangil
}

\begin{tabular}{|c|c|}
\hline CH RON I C LE & A B S T RACT \\
\hline $\begin{array}{l}\text { Article history: } \\
\text { Received October 28, } 2015 \\
\text { Received in revised format } \\
\text { November } 28,2015 \\
\text { Accepted December } 22,2015 \\
\text { Available online } \\
\text { December } 28,2015 \\
\text { Keywords: } \\
\text { Salary } \\
\text { Performance appraisal } \\
\text { Training \& development } \\
\text { Career growth } \\
\text { Organizational commitment } \\
\text { Turnover intention }\end{array}$ & $\begin{array}{l}\text { Retaining the best employees is of high concern for most organizations and this issue has } \\
\text { become a significant focus of attention for many researchers. For this reason, this paper } \\
\text { discusses different factors which influence the employee turnover intention-behavior in the } \\
\text { organization, specifically to examine the effect of salary, performance appraisal, training \& } \\
\text { development and career growth on turnover intention. In addition, based on the social exchange } \\
\text { theory this paper explains the mediating role of organizational commitment in the relationship } \\
\text { between human resource development factors, career growth and turnover intention. A cross } \\
\text { sectional, survey data study is undertaken to investigate the relationships in a sample of } 270 \text { full } \\
\text { time faculty members employed in different private universities of Pakistan. Partial Least } \\
\text { Square two step path modeling is used to test the direct and the indirect hypothesis of the study. } \\
\text { The results of PLS (SEM) path modeling reveal that human resource development factors } \\
\text { specially salary and performance appraisal were negatively associated with turnover intention. } \\
\text { In addition, the results also indicate that career growth had significant relationships with } \\
\text { turnover intention. Moreover, out of four dimensions of career growth, only two dimensions, } \\
\text { namely promotion speed and remuneration growth, have strong influence on turnover intention. } \\
\text { Finally, in terms of organizational commitment as mediating variable between the relationships } \\
\text { of salary, performance appraisal, career growth and turnover intention, four out of six variables } \\
\text { indicate partial mediation including career growth (career goal progress), career growth } \\
\text { (promotion speed), career growth (remuneration growth) and performance appraisal. }\end{array}$ \\
\hline
\end{tabular}

\section{Introduction}

The phenomenon of employee turnover has become a major concern of employers, as it indicates an ongoing challenge for contemporary practitioners and researchers (Abdulkareem et al., 2015). For example, In the United States of America (U.S.A.), about 7.7\% of the full time faculty members from various universities and colleges had left their posts for other institutions (Abdulkareem et al., 2015). Among these academicians, only 30\% were being retires, whilst the remaining $70 \%$ had left their institutions for number of reasons (Abdulkareem et al., 2015). Similarly, according to Long et al., 
(2014) and Abdulkareem et al. (2015) recent estimates have indicated that from 2012 to 2015, approximately around 19,000 professionals, which includes medical staff, lecturer from various colleges and universities leave Asia-pacific every year to look for a better opportunities in Western countries such as United States, Canada, Germany and United kingdom, among others. Other than that, in the context of higher education institution of Pakistan, majority of the qualitative and quantitative research findings indicate that faculty turnover is one of the major problem for higher education institution especially in private universities of Pakistan due to high switching rate of academicians as compare to public universities of Pakistan (Khan et al., 2014; Mubarak, 2012; Yusoff \& Khan, 2013).

Researcher generally observed turnover and its proxy, turnover intentions as the withdrawal procedure of employee. Price (2001) and Cotton and Tuttle (1986), initially defined turnover behavior as "the movement of employee to other organizations", whereas the term turnover intention signify "the employees perceived possibility of leaving the existing organization".

Hence, employee turnover will continue to become a serious problem faced by all organizations around the world and employers need to be creative in handling this problem by identifying the various factors to understand the reasons why employees might decide to leave their organizations (Monama, 2015). Generally, there are some studies to see the reasons on why employees might decide to leave their organizations (Abdulkareem et al., 2015). For example, majority of the previous studies have revealed that human resource practices may affect employees turnover intention (Giauque et al., 2010; Pirzada et al., 2013; Juhdi et al., 2013; Yean \& Yahya, 2013; Long et al., 2014; Abdulkareem et al., 2015). Other than that, some studies have demonstrated that individual variables such as job alternatives, (Maertz \& Campion, 1998); autonomy, organizational justice, job stress, pay, promotional chances, and social support (Kim et al., 1996); person-organization fit (O'Reilly et al., 1991); job incompatibility (Chun \& Wang); citizenship behavior (Chen et al., 1998); task-related ability (Jackofsky \& Peters, 1983); job performance (Martin et al., 1981; McElroy et al., 2001); absenteeism (Farrel \& Stamm, 1998); organizational, work, and personal factors (Porter \& Steers, 1974). But limited number of research works has considered human resource development factors in explaining employee turnover behavior. Indeed there are many studies that have been done to understand the factors that might affect turnover intention. Therefore, none of these studies have the career stage theory and social exchange theory to explain these relationships.

To fill up this theoretical gap, the current research extend previous literature by examining organizational commitment as an important mechanism by which human resource practices and its various functions such as salary, performance appraisal, training and development and career management practices like career growth could be related to employee's turnover intention. Organizational Commitment (OC) has long been acknowledged as the key variable in the working relationship that has also been widely accepted the way to decrease volunteer turnover by enhancing employee organization commitment (Raihan, 2012). Within the organizational settings, organizational commitment might be defined as "the psychological attachment felt by the employee for the organization or psychological state of mind which binds the individual to the organization (Allen \& Meyer, 1990).The significant role of commitment as a mediating variable on the relationship between salary, performance appraisal, training and development and career management practices like career growth and employee's turnover intention can be supported by social exchange theory (Blau, 1964), which postulates that employees' attitudes and behaviors' are substantially influenced by perceptions of organizational commitment. Hence, based on social exchange theory, it is suggested that when individuals perceived that they are in a good social exchange relationship with their organizations, they are less likely to quit their jobs. Furthermore, when individuals developed positive perception in terms of salary, performance appraisal, training and development and career growth, they will reciprocate by remaining on their present job (Abdulkareem et al., 2015). However, few studies have empirically tested this proposed relationship (Vandenberghe \& Tremblay, 2008; Kantor, 2013; Si \& Li, 2012; A'yuninnisa \& Saptato, 2015). 


\section{Literature Review and Conceptual Framework Development}

\subsection{Salary and Turnover Intention}

In this era of globalization direct financial payment which is mainly concerned about financial return and benefits employees received as part of an employment relation such as salary has become significant focus of attention for researchers and academicians now a days. In 1981, Lawler define salary as "all cash incentives and the fringes benefits mix that an employee from an organization". Dessler (2007) expands the definition of salary as "financial returns and tangibles benefits employees received as part of an employment relation". On the other hand, Heathfield, (2014) defined salary as "a fixed amount of money and compensation which is paid to an employee by an employer in return of work performed".

Literature related to salary and turnover intention highlighted that salary as one of the greatest significant components for turnover decision (Shahzad et al., 2008; Kim, 2005; Ovadje, 2009; Sattar \& Ahmad, 2014). In this regard, majority of the previous literature revealed that when employees perceives better and equitable salaries within the organization, they are less likely to leave the organization (Liu, 2012; Kroon \& Freese, 2013; A'yuninnisa \& Saptato, 2015).

Furthermore, in the context of Pakistan Sattar and Ahmad (2014) who claimed that salary has been major aspect of HRM in developing countries like Pakistan where employees are generally low paid with little remuneration growth and benefits. While Shahzad et al. (2008) reveled that salary of the faculty may be a best tool in retaining experienced and skilled faculty. However, organizations need to be aware that human resource practices, significantly salary, could create links, make better fits, and create greater potential sacrifices for employees who may be looking elsewhere for employment. In addition, Pakistan is one of the least developed countries, where 22.3 percent of people living below the poverty line. In this regard, the number of job openings is not that much as compared with the developed countries, high inflation rate that makes the living expenses so high. Therefore, the money matters in such situation. However, the perception of salary among faculty is negatively related to turnover intention.

Therefore, this research proposed that salary is negatively associated to turnover intention, that is, higher the salary for workers, lesser the employee turnover for the organization. Based on the above discussed literature the recommended proposition is;

Hypothesis 1: There is a negative relationship between salary and turnover intention.

\subsection{Performance Appraisal and Turnover Intention}

Another factor that is believed to have impact on turnover intention is performance appraisal which is viewed as an important mechanism for changing employees' attitude and behaviors such as organizational commitment and turnover intention (Morrow, 2011). In 1962, Mincer initially defined performance appraisal as "the basic managerial function such as evaluation of employees' performance periodically to improve the utilization of human resources within the organization". Some other authors like, Tower (1996) defined performance appraisal as "systematic review of the performance of staff, on a written basis, at regular time intervals; and the holding of appraisal interviews at which staff have the opportunity to discuss performance issues past, present and future, on a one-to-one basis, usually with their immediate line manager" (citied from Zhazykpayeva, 2011).

Process of evaluating the performance of employees, i.e. performance appraisal is one of the most important issue due to its positive influences on development of the human capital resulting in higher performance, increased motivation and job satisfaction, whereas, neglecting those aspects would lead to negative effects which may increase voluntary employee turnover rate (Zhazykpayeva, 2011; Rubel $\&$ Kee, 2015). On the other hand, according to Al-shuaibi and Shamsudin, (2013) performance appraisal is vital tool of organizations for number of human resource development activities such as 
enhance employee performance, access employees and develop their competence, help organization to identify high achievers, distribute reward such as merit pay, promotion, help to access the training needs for career development and also significantly to reduce employee turnover.

In recent years, majority of the empirical studies have been undertaken to examine the direct relationship between performance appraisal and turnover intention. Different conclusions have been found in different researches for example; on the one hand researchers claimed that performance appraisal had negative effect on employee turnover intention which implies that when employees perceives their performance appraisal procedure along with other HR practices to be fair and just, their intention to leave the organization is minimized (Abdulkareem et al., 2015; Kadiresan et al., 2015; Rabiul \& Kee, 2015; Yean \& Yahya, 2013; Mustapha et al., 2013). Second, some of the studies claimed that when performance appraisal is based on politics and not fair then chances are maximized for employees' intent to leave or switch the organization (Aziz et al., 2013; Poon, 2004; Salleh et al., 2013)

Despite all the arguments that highlight the importance of performance appraisal on turnover intention, studies that relate these two variables are limited. Although, majority of the studies related to performance appraisal carried out in the western context and mainly focus banking sector, retailing sector, public sector which exclude Pakistani organizations particularly academia with different context. In addition, in higher education institution performance appraisal was ignored in the previous studies. So that's why, current empirical study conducted in Asian context particularly in the Pakistani context as opposed to western context.

Therefore, this research proposes that performance appraisal is negatively associated to turnover intention, that is, when employees perceives their performance appraisal procedure along with other HR practices to be fair and just, their intention to leave the organization is minimized. Based on the above discussed literature the recommended proposition is;

Hypothesis 2: There is a negative relationship between performance appraisal and turnover intention.

\subsection{Training and development and Turnover Intention}

Training/development was acknowledged as one of the major components of human resource practices in the area of human resource management and has been defined as "An investment in acquisition of skill or in improvement of employee productivity" (Mincer, 1962). Similarly, most of the organizations invest in their employees in order to increase the productivity and skill which ultimately decrease their intent to leave the organization (Mincer, 1962).

The relationship between training \& development and turnover intention has received much more attention among academicians and researcher after Becker's theory of investing in human capital by offering training programs which build skills and improve employee's productivity. Many studies have been undertaken from different prospectives to investigate how and why training and development influence turnover intention for example human capital (Chun \& Wang, 1995; Becker, 1962), social exchange (Eisenberger et al., 2001) and human resource prospective (Appleby et al., 2000). Many studies explore the link between training \& development and turnover intention. For instance, according to Grace and Khalsa (2003) and Rosser (2004), the research on faculty turnover intention clearly shows a link between the training and turnover intention, whereas the study by Martin (2003) claimed that organization offers training to improve the competency and skills of existing employees to tackle the turnover issue in the organization.

In the past, majority of the empirical studies have been undertaken to examine the direct relationship between training and development and turnover intention. Different conclusions have been found in previous researches for example; on the one hand researchers claimed that training and development had negative effect on employee turnover intention, which implies that when employees perceives better and good training programs for their career development within the organization, they are less likely to leave the organization (Abdulkareem et al., 2015; Chew \& Chan, 2008; Dardar et al., 2012; 
A'yuninnisa \& Saptato, 2015; Yean \& Yahya, 2013; Samuel \& Chipunza, 2009; Juhdi et al., 2013). Second, some of the studies claimed that training leads to better skilled and productive employees who are more employable in other organizations, which implies that training \& development had positive relationship with turnover intention (Cheng \& Waldenberger, 2013; Verhees, 2012). Third some of the studies claimed that training and development had no significant effect on employee turnover intention(Mincer, 1988; Egan et al., 2004; Levine, 1993; Verhees, 2012).

Despite all the arguments that highlight the importance of training \& development on turnover intention, studies that relate these two variables are limited. Nevertheless, the literature has so far been focusing on training \& development has two shortcomings. First, in past some of studies indicates inconsistency between the relationship of training \& development and turnover intention. Second, scholars have traditionally focused on western organizations even though training and retention of employees presently highly needed by Pakistani organization particularly academia with different context. So that's why, current empirical study conducted in Asian context particularly in the Pakistani context as opposed to western context. Because Pakistan faces a severe shortage of qualified employees especially in higher education which is harmful of its economic growth. On the other hand, gone is the fantasy, attached with the public sector due to the lack of permanent opportunities and short time projects which ultimately increased the rates of un-employment. During the course of last one decade, private sector in Pakistan has grown to its maximum utility due to better compensation and benefits, training \&development programs and career growth. This chaos and saturation in public sector has increased the employment rate in private sector. According to Pakistan Labor Force Survey, (20132014) by Amin, 60 percent individuals working in private sector and 40 percent were working in public sector. Other than that, employment opportunities are not covering the Growing population size of Pakistan comprised of total population of 19 billion. Other than that, there is strong evidence that most training practices and programs comes from west and don't meet the expectation and need in Pakistani context due to cultural differences.

So based on the social exchange theory and majority of previous literature this study proposed that there would be negative relationship between training and development and turnover intention. This infers that when employees perceive better and good training programs for their career development within the organization, they are less likely to leave the organization.

Hypothesis 3: There is a negative relationship between training \& development and turnover intention.

\subsection{Career growth and Turnover Intention}

Career growth has been defined as "the degree of professional upward mobility within the organization" (Weng \& Hu, 2009). In accordance to Price (2001) career growth and development carries satisfaction between the employees and decreases their intent of leaving the organization.

In this regard, career management is a practice whereby organizations provide career counseling, training, mentoring, career paths, and career planning workshops to their employees (Schnake et al., 2007). Studies that link career management and turnover intention are not many (e.g. Guan et al., 2015; Schnake, et al., 2007), but all of them agree that turnover intention is less among employees who work for organizations that are perceived to help employees with career management. Career management practices is important because it argued that employees are very much concerned about their possibility of career growth whether in the organizations they are currently working for or in other organizations (Karavardar, 2014). Furthermore Karavardar (2014) also argued that to retain employees, organization should focus on career growth and career concerns policies that could create psychological contract with its employees. As such, employees who expect progress and growth in their career will ultimately stay longer in the organization, which means turnover intention will become less.

Nonetheless, before it can be safely concluded that career management practices could indeed be beneficial to reduce turnover intention among employees, there is a need to determine whether employees turnover intention are affected by their career growth and Career concern or not. Currently 
available research that relate career growth to turnover intention a quite a few, and some of them is the study by Nouri and Parker (2013), Weng and Hu (2009), Weng and McElroy (2012), Karavardar, (2014). Weng and $\mathrm{Hu}(2009)$ suggested that the professional growth of employees could be captivated by four dimensions: career goal progress, professional ability development, promotion speed, and remuneration growth. This multidimensional conceptualization means that career growth is simultaneously a feature of employee efforts on making progress toward their career objectives and the acquiring new skills and the organization's efforts rewarding these efforts, by promotions and salary increases.

Moreover, in accordance with the social exchange theory (Blau, 1964) it assumed that encouraged and promoted employees feel appreciated through the organization is most likely to reimburse the organization by his or her commitment and contribution towards the organization and less likely to leave the organization. Therefore, based on the social exchange theory and majority of previous literature this study proposed that there would be a negative relationship between career growth and turnover intention. This infers that employees who seek to get proper remuneration and promotion growth in their organizations will ultimately make it less likely their employees think about leaving their jobs.

Hypothesis 4: There is a negative relationship between career growth (career goal progress, professional ability development, promotion speed, and remuneration growth) and turnover intention.

\subsection{Organizational commitment as Mediator}

The current research extends previous literature by examining organizational commitment as an important mechanism by which human resource practices and its various functions such as salary, performance appraisal, training and development and career management practices like career growth could be associated with employee's turnover intention. Organizational Commitment (OC) has long been acknowledged as the key variable in the working relationship that has also been widely accepted the way to decrease volunteer turnover by enhancing employee organization commitment (Raihan, 2012). Within the organizational settings, organizational commitment might be defined as "the psychological attachment felt by the employee for the organization or psychological state of mind which binds the individual to the organization" (Allen \& Meyer, 1990). Additionally, Rabiul et al. (2015) and Karavardar, (2014) claimed that organizational commitment had negative influence on employee turnover intention, which means that i.e. the higher the organizational commitment the lowers the intention to leave the organization. Likewise, this result is also correlated with other studies which found that employees with higher level of commitment tend to report lower intention to leave the organization (Lee \& Huang, 2012; Raihan, 2012; Weng \& McElroy, 2012). While Raihan (2012) claimed that organizational commitment significantly influence faculty turnover intention, which means that faculty members wanted to remain with organization because they need to maintain benefits they derived from their organizations. Majority of the Literature related to organizational commitment and turnover intention highlighted that organizational commitment has negative relationship with employee turnover intention such as (Lee \& Huang, 2012; Raihan, 2012; Weng \& McElroy, 2012; Rabiul et al., 2015). Therefore, from the supported previous literature, it can conclude that organizational commitment is one of the strongest and imperative predictor of employee turnover intention. Thus following relationship can be proposed.

Hypothesis 5: There is a negative relationship between organizational commitment and turnover intention.

The significant role of commitment as a mediating variable on the relationship between salary, performance appraisal, training and development and career management practices like career growth and employee's turnover intention can be supported by social exchange theory (Blau, 1964), which postulates that employees' attitudes and behaviors' are substantially influenced by perceptions of organizational commitment. Hence, based on social exchange theory, it is suggested that when 
individuals perceived that they are in a good social exchange relationship with their organizations, they are less likely to quit their jobs. Furthermore, when individuals developed positive perception in terms of salary, performance appraisal, training and development and career growth, they will reciprocate by remaining on their present job (Abdulkareem et al., 2015).

Organizational commitment as a mediating variable on the relationship between salary, performance appraisal, training and development and career management practices like career growth and employee's turnover intention, was supported by recent studies. Like, empirical studies have demonstrated that the relationship between salary and turnover intention were mediated by organizational commitment, if employees perceived higher, attractive and equitable internal salary system within the organization, they would stay in organizations and the chance to quit the organization could be minimized (Vandenberghe \& Tremblay, 2008; Kantor, 2013; Si \& Li, 2012; N, Rizqi, 2015 ). On the other hand, importance of organizational commitment on the relationship between performance appraisal and employee turnover intention was supported by recent empirical studies, like study conducted by Rabiul et al., (2015), who claimed that commitment of employees will enhance if they find fair and well deigned performance system. Likewise, some other studies which found that fairness and just in performance appraisal strengthen the feelings of employees the organization, this psychological experience of performance appraisal system leads employees to be more committed to the organization and limit their thinking of switching or quitting the job (Ikramullah et al., 2012; Lau \& Moser, 2008).

Furthermore, career management practices is important because it argued that employees are very much concerned about their possibility of career growth (Karavardar, 2014). Furthermore Karavardar (2014) also argued that to retain employees, organization should focus on career growth and career concerns policies that could create psychological contract with its employees. As such, employees who expect progress and growth in their career will ultimately stay longer in their organizations, which means turnover intention will become less. Likewise, Weng and Hu, (2009) and Weng and McElroy, (2012) conducted empirical studies on career growth and their influence on occupational commitment and turnover intentions. According to their research, they argued that career growth was negatively associated with intention and also found occupational commitment as partial mediator on the relationship. Furthermore, Hess et al. (2012) argued that turnover intention is less among employees who work for organizations that are perceived to help employees with career management. According to literature summary, it can be concluded that, when organizations provide career opportunities to their employees, by awarding internal promotions and remuneration to improve their professional skills and career goal progress, these employees are more ready to reciprocate by moral obligation to their organizations and think less to leave the organization. Hence, based on social exchange theory, it is suggested that when individuals perceived that they are in a good social exchange relationship with their organizations, they are less likely to quit their jobs. Furthermore, when individuals developed positive perception in terms of salary, performance appraisal, training and development and career growth, they will reciprocate by moral obligation to their organization and think less to leave the organization. So based on the social exchange theory and majority of previous literature this study proposed that organizational commitment mediates the relationships among salary, performance appraisal, training and development and career management practices like career growth and employee's turnover intention.

Hypothesis 6: The relationship between salary and turnover intention is mediated by organizational commitment.

Hypothesis 7: The relationship between performance appraisal and turnover intention is mediated by organizational commitment.

Hypothesis 8: The relationship between training \& development and turnover intention is mediated by organizational commitment. 
Hypothesis 9: The relationship between career growth (career goal progress, professional ability development, promotion speed, and remuneration growth) and turnover intention is mediated by organizational commitment.

\section{Methodology}

\subsection{Research Respondents}

The respondents for this study are full-time faculty members working at various private universities, mainly located in Punjab and Khyber Pakhtunkhwa Pakistan. According to Educational Statistics of Pakistan (2013-2014) report, there are 64 private universities established countrywide. However, only 32 private universities located in the Punjab and Khyber Pakhtunkhwa were selected for the present study by employing cluster sampling technique. There are about 7912 faculty members working as fulltime in these 32 private universities, and represent the total population of the study.

\section{Table 1}

Demographic Profile of Response

\begin{tabular}{|c|c|c|c|}
\hline Demography & Description & No. of Responses & $\%$ \\
\hline \multirow[t]{2}{*}{ Gender } & Male & 160 & 59.3 \\
\hline & Female & 110 & 40.7 \\
\hline \multirow[t]{3}{*}{ Marital Status } & Married & 132 & 48.9 \\
\hline & Not Married & 130 & 48.1 \\
\hline & Divorced & 8 & 2.6 \\
\hline \multirow[t]{4}{*}{ Age } & Less than 30 Year & 144 & 53.3 \\
\hline & 30-40 Year & 81 & 30.0 \\
\hline & 41-50 Year & 36 & 13.3 \\
\hline & More than 50 Year & 9 & 3.3 \\
\hline \multirow{5}{*}{ Present Position } & Lecturer & 157 & 58.1 \\
\hline & Senior Lecturer & 47 & 17.4 \\
\hline & Assistant Professor & 52 & 19.3 \\
\hline & Associate Professor & 7 & 2.6 \\
\hline & Professor & 7 & 2.6 \\
\hline \multirow[t]{5}{*}{ Working Experience } & Less than 1-Year & 68 & 25.2 \\
\hline & 1-3 Year & 94 & 34.8 \\
\hline & 4-6 Year & 61 & 22.6 \\
\hline & 7-10 Year & 34 & 12.6 \\
\hline & More than 10 -Year & 13 & 4.8 \\
\hline \multirow[t]{2}{*}{ Qualification } & Master or Equivalent & 208 & 77.0 \\
\hline & PhD or Equivalent & 62 & 23.0 \\
\hline
\end{tabular}

In determining an appropriate sample which could produce a reliable results for the study, Hair et al, (2011) suggested that good sample size for statistical analysis at least 10-20 times more than variables is needed. Additionally, Hair et al. $(2011 ; 2014)$ recommended that minimum sample size for PLS analysis is about 220 respondents. Hence, a total of 550 questionnaires were personally distributed to the full time permanent faculty member of universities to ensure enough data can be collected for analysis. Out of $550,53 \%$ of the questionnaires were returned. However, only 270 questionnaires were usable for further analysis, while 24 of them were rejected because the major part of the questionnaire was left as blank. The distribution and collection of questionnaires were carried out in period of five months from November, 2014 to March, 2015. Table 1 shows the demographic profile of the 270 respondents of this study. In summary, the majority of the respondents are less than 30 years (54\%), are male $(59.3 \%)$, are married (49\%), are equipped with Master degree (77\%), have work experience 1-3 year (35\%), and holding Lecturer position in the organization $(58 \%)$.

\subsection{Measurement}

The scales used to measure all variables included in this study have been adapted from the previous researchers with appropriate modification that is suitable for the sample. The survey questionnaires were consisting of mainly two components. First component comprised of several Likert-type scale items, and the second component described the demographic information of the faculty members (the respondents) of this study. The Likert scale is designed to examine how strongly the respondents agree 
or disagree with a certain statement (Sekaran, 2006). The purpose of a 7-point Likert scale was to offer respondents more options/choice and better capture variability in their attitudes and feelings (Hinkin, 1995). To measure salary, 5- items scale by Tessema and Soeters, (2006) was adapted. Likewise, to measure training \& development, 3- items scale by Delery and Doty, (1996) was adapted. Similarly, performance appraisal was measured with 3-items scale by Chang, (2005) was adapted. Moreover, for career growth (career goal progress, professional ability development, promotion speed, and remuneration growth) a 15 items scale by Weng and $\mathrm{Hu}$ (2009) was employed. Organizational commitment a 6-items scale by Gould-Williams and Davies, (2005) was employed. Lastly, turnover intention was measured with 5 items used by Wayne et al. (1997) and Lum et al. (1998).

\section{Data Analysis and Results}

\subsection{Assessment of the Measurement Model}

In model evaluation, the measurement model was undertook to insure about the model validity and reliability. Based on partial least square structural equation modeling, the assessment of measurement model was examined by using SmartPLS 2.0 (Ringle et al., 2005). To determine the measurement model convergent validity, discriminant validity and reliability of the measurement of construct have been examined.

Table 2

Results of Measurement Model

\begin{tabular}{|c|c|c|c|c|c|}
\hline Construct & Item & Loadings & Cronbachs & Composite & Average Variance \\
\hline \multirow[t]{3}{*}{ Career goal progress (CGP) } & CGP1 & 0.725 & 0.638 & 0.805 & 0.579 \\
\hline & CGP3 & 0.754 & & & \\
\hline & CGP4 & 0.801 & & & \\
\hline \multirow{2}{*}{ Professional ability development (PAD) } & PAD3 & 0.928 & 0.819 & 0.917 & 0.847 \\
\hline & PAD4 & 0.913 & & & \\
\hline \multirow{3}{*}{ Promotion speed (PS) } & PS1 & 0.693 & 0.644 & 0.789 & 0.556 \\
\hline & PS2 & 0.703 & & & \\
\hline & PS3 & 0.833 & & & \\
\hline \multirow[t]{2}{*}{ Remuneration growth (RG) } & RG1 & 0.874 & 0.740 & 0.885 & 0.793 \\
\hline & RG2 & 0.907 & & & \\
\hline \multirow{5}{*}{ Organizational commitment } & $\mathrm{OC} 1$ & 0.760 & 0.886 & 0.917 & 0.690 \\
\hline & OC3 & 0.838 & & & \\
\hline & $\mathrm{OC} 4$ & 0.883 & & & \\
\hline & OC5 & 0.871 & & & \\
\hline & OC6 & 0.794 & & & \\
\hline \multirow{3}{*}{ Performance appraisal } & PA1 & 0.946 & 0.838 & 0.906 & 0.766 \\
\hline & PA2 & 0.715 & & & \\
\hline & PA3 & 0.945 & & & \\
\hline \multirow{3}{*}{ Salary } & SA2 & 0.871 & 0.779 & 0.871 & 0.692 \\
\hline & SA3 & 0.777 & & & \\
\hline & SA4 & 0.845 & & & \\
\hline \multirow{3}{*}{ Training and development } & TD1 & 0.771 & 0.633 & 0.803 & 0.576 \\
\hline & TD2 & 0.717 & & & \\
\hline & TD4 & 0.787 & & & \\
\hline \multirow{5}{*}{ Turnover intention } & TI1 & 0.842 & 0.800 & 0.862 & 0.559 \\
\hline & TI2 & 0.645 & & & \\
\hline & TI3 & 0.792 & & & \\
\hline & TI4 & 0.673 & & & \\
\hline & TI5 & 0.767 & & & \\
\hline
\end{tabular}

Before determining the convergent validity, the researcher examined loading and cross loadings of all items of the study variables to point out any problem which serve as a pre requisite for measurement model. As argues by Hair et al. $(2010 ; 14)$ convergent validity is obtained when the factor loading of all the items higher than 0.5 and no loading of any item from other construct have higher loading than the 
one which think to measure. Regarding this study concerned out of 37 items 29 items have their loading above than 0.5 as shown Table 2. Table 2 demonstrated Cronbachs alpha, composite reliability and average variance extracted (AVE) values of all constructs. According to (Fornell \& Larcker, 1981; Hair et al., 2014) the composite reliability should be accepted at least 0.70 and AVE should be at 0.50 . As shown in the Table 2, all the constructs have high reliability and their average variance extracted (AVE) is greater than cut off point of 0.50 which is indication of reliability of the measurement model. This study calculated Cronbachs Alpha to find out internal consistency of the data. According to (George \& Mallery, 2003) which provide the rule of for deciding the value alpha; " $\alpha>0.9$ - Excellent, $\alpha<0.8$ Good, $\alpha<0.7-$ Acceptable. As for as this study concerned Table 2 indicates that all constructs have Cronbachs Alpha value more than 0.6. So this is the indication of all the variables in the study have good consistency.

Discriminant validity was conducted to assure the external consistency of the model, based on the correlation between the latent variables the constructs were compared with square root of AVEs. As shown in Table 3 all the correlations between the constructs are lower than square root averages (AVEs) of which are bolded in diagonal.

\section{Table 3}

Discriminent validity of the Variables

\begin{tabular}{|c|c|c|c|c|c|c|c|c|c|}
\hline & CGP & PAD & PS & $\mathrm{RG}$ & $\mathrm{OC}$ & PA & SA & TD & TI \\
\hline CGP & 0.760872 & & & & & & & & \\
\hline PAD & 0.527294 & 0.920206 & & & & & & & \\
\hline PS & 0.498217 & 0.644359 & 0.745704 & & & & & & \\
\hline $\mathrm{RG}$ & 0.638637 & 0.332485 & 0.34501 & 0.890567 & & & & & \\
\hline $\mathrm{OC}$ & 0.107407 & 0.258786 & 0.441196 & 0.242109 & 0.830399 & & & & \\
\hline PA & 0.16752 & 0.225361 & 0.161462 & 0.149231 & 0.164141 & 0.875089 & & & \\
\hline SA & 0.30528 & 0.118302 & 0.300039 & 0.27991 & 0.238123 & 0.164388 & 0.832079 & & \\
\hline TD & -0.28925 & -0.22696 & -0.30473 & -0.3374 & -0.19762 & -0.17686 & -0.53777 & 0.75906 & \\
\hline TI & -0.36932 & -0.38785 & -0.50724 & -0.4117 & -0.36018 & -0.30093 & -0.36487 & 0.368121 & 0.74756 \\
\hline
\end{tabular}

\subsection{Assessment of Structural Model Direct Relationships}

After accessing the measurement model, the structural model was assessed by using SmartPLS 2.0. To assess the structural model hypothesis testing with path coefficient and T-value, effect size and predictive relevance of the model were examined.

\subsubsection{Direct Hypothesis Testing}

In PLS, structure model gives inner modeling analysis of the direct relationship among the constructs of the study and their t-values as for as path coefficients. As argued by Henseler et al. (2009), the path coefficient is the same like standardized beta coefficient and regression analysis. Where beta values of the coefficient of the regression and t-values are examined to decide on the significance. Following the rule of thumb by Hair et al., (2014), Boostraping method was performed (with 500 sampling iterations for 270 cases / observations) to obtain beta values of the coefficient of the regression and t-values which greater than 1.64 is considered to be as significant, which is further used for making decisions on the purposed hypothesis.

The basic purpose of this study is to focus on model evaluation with examination of direct relationships and secondly to test the hypothesized relationships among the constructs through structural model. In this study fifteen (15) hypotheses which have direct relationships were tested, out of fifteen (15) ten (10) were proven to be supported and five (5) were not supported. Fig.1. explain the direct effect of every latent variable on the dependent variable. 


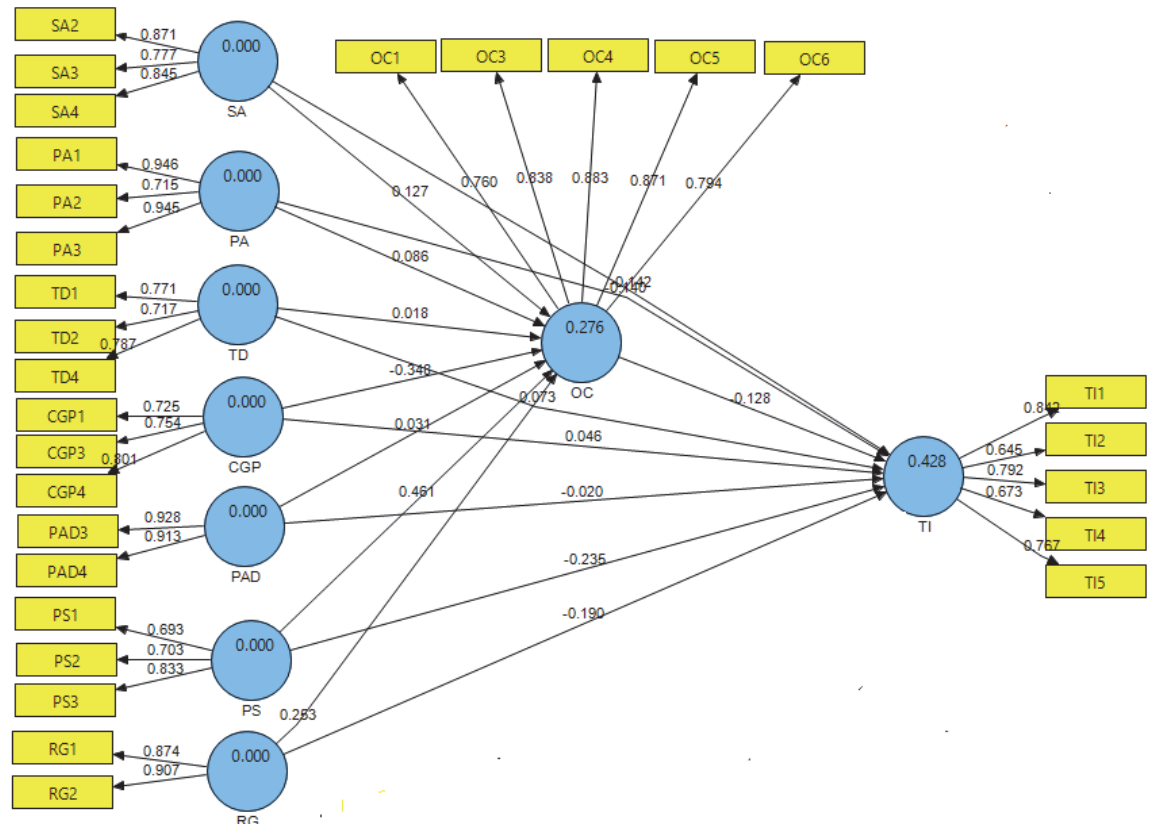

Fig.1. Measurement Model of the Study

Table 4 illustrates that all hypotheses that were supported and accepted have t-value greater than 1.64 and the hypotheses which are rejected had t-value less than 1.64. Fig.1. was fully explained in Table 4 which shows the effect of all constructs on dependent variable turnover intention. The R-square value which derived from the output of PLS shows that all the constructs put together have tendency of influencing $43 \%$ of the changes independent variable.

Table 4

Summary of Direct Hypothesis Testing

\begin{tabular}{cccccc}
\hline NO & Hvpothesized Path & Path & Standard & T Value & Findings \\
\hline 1 & CGP - > OC & -0.330 & 0.083 & 4.190 & Supported \\
2 & CGP - TI & 0.041 & 0.076 & 0.597 & Not supported \\
3 & PAD - > OC & 0.028 & 0.070 & 0.442 & Not supported \\
4 & PAD -> TI & -0.025 & 0.076 & 0.263 & Not supported \\
5 & PS - > OC & 0.463 & 0.070 & 6.601 & Supported \\
6 & PS - TI & -0.223 & 0.082 & 2.875 & Supported \\
7 & RG - > OC & 0.239 & 0.077 & 3.284 & Supported \\
8 & RG - > TI & -0.186 & 0.065 & 2.942 & Supported \\
9 & OC - TI & -0.126 & 0.054 & 2.366 & Supported \\
10 & PA - OC & 0.083 & 0.052 & 1.655 & Supported \\
11 & PA - TI & -0.138 & 0.048 & 2.909 & Supported \\
12 & SA -> OC & 0.128 & 0.064 & 1.996 & Supported \\
13 & SA -> TI & -0.140 & 0.054 & 2.645 & Not supported \\
14 & TD -> OC & 0.016 & 0.067 & 0.268 & Not supported \\
15 & TD - $>$ TI & 0.077204 & 0.056962 & 1.2774 &
\end{tabular}

\subsubsection{Effect size}

The effect size signifies the relative effect of a specific exogenous latent variable on endogenous latent variable(s) by indicating change in the R-squared (Chin, 1998; Hair et al., 2014). It is determined as the increase in R-squared of the latent variable to which the path is associated, relative to the latent variable's proportion of unexplained variance (Chin, 1998; Hair et al., 2014). Therefore the effect size could be depicted using the following formula (Cohen, 1988; Callaghan et al., 2007):

Effect size $f^{2}=\frac{R_{\text {Inclued }}^{2}-R_{\text {Excluded }}^{2}}{1-R_{\text {Inclued }}^{2}}$ 
Cohen (1988) explains $f^{2}$ values of $0.02,0.15$ and 0.35 as having weak, moderate, strong effects respectively. Table 5 demonstrates the particular effect sizes of the latent variables of the structural model.

Table 5

Effect size of Latent Variables

\begin{tabular}{ccccc}
\hline R-squared & Included & Excluded & f-squared & Effect size \\
\hline SA -> TI & 0.428 & 0.397 & 0.054 & Small \\
PA -> TI & 0.428 & 0.393 & 0.061 & Small \\
TD -> TI & 0.428 & 0.409 & 0.033 & Small \\
CG -> TI & 0.428 & 0.309 & 0.208 & Medium \\
OC - > TI & 0.428 & 0.413 & 0.026 & Small \\
\hline
\end{tabular}

As mentioned in Table 5, the effect sizes for salary, performance appraisal, training and development, career growth and organizational commitment on turnover intention, were $0.05,0.06,0.03,0.20$ and 0.02, respectively. Therefore, following Cohen's (1988) guideline, the effects sizes of these exogenous latent variables on turnover intention could be viewed as small, small, small, medium and small, respectively. In line with the argument of Chin et al. (2003), who emphasis that even the minutest strength of $\mathrm{f}^{2}$ might be considered because, they can affect the dependent variable in their own way.

\subsection{Structural Model with Mediation}

Re-sampling mediation technique (bootstrapping) was used by researchers to test the indirect effect of each potential variable. Likewise, majority of the researcher revealed that Bootstrapping a nonparametric re-sampling procedure was getting more attention for prospective researcher because this is one of the most rigorous and powerful procedure for testing the mediation effect (Hayes, 2009; Zhao et al., 2010). According to Hair et al. (2014) this bootstrapping for mediation analysis is said to be best suited for PLS-SEM because it can be applied to small sample size. In line with suggestion of Hair et al. (2014) when testing the mediation effects, the researchers must follow Preacher and Hayes (2004: 2008) and bootstrap the sampling distribution of the indirect effects that work for simple and multiple models. Current study tested the effect of organizational commitment as mediating variable with SmartPLS 2.0 M3 (Ringle et al., 2005) using the bootstrapping with re-sample of 500 and model displayed the t-values.

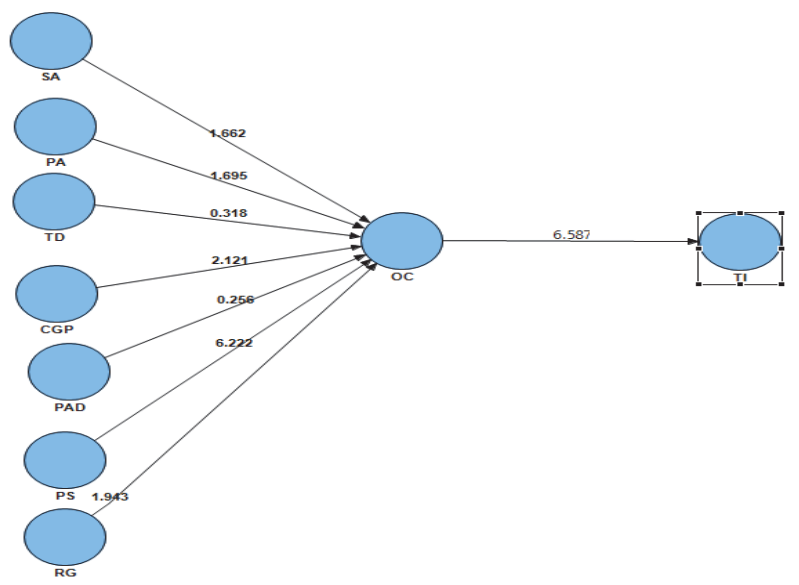

Fig. 2. The indirect effect of $O C$

From the structural model assessment of this study, it was found that out of all study variables included in the structural model only salary, performance appraisal and three dimension of career growth names 
as career goal progress, promotion speed and remuneration growth were significantly associated with organizational commitment and turnover intention.

Table 6 shows the results of mediation effect of organizational commitment on the relationships between independent variable and dependent variable.

Table 6

Test of Mediation of Organizational Commitment

\begin{tabular}{ccccccc}
\hline NO & CGP $>$ OC $>$ & PAD $>$ OC $>$ & PS $>$ OC $>$ TI & RG $>$ OC $>$ & SA $>$ OC $>$ & PA $>$ OC $>$ TI \\
\hline $\mathrm{a}^{*} \mathrm{~b}$ & 0.055 & -0.008 & -0.064 & -0.037 & -0.011 & -0.02 \\
STDVA & 0.020 & 0.008 & 0.029 & 0.015 & 0.007 & 0.01 \\
T-VALUE & 2.71 & 0.99 & 2.19 & 2.41 & 1.52 & 1.95 \\
P-VALUE & 0.003 & 0.162 & 0.014 & 0.008 & 0.065 & 0.026 \\
\hline
\end{tabular}

Table 6 shows that four out of six variables indicate mediation including career goal progress with tvalue of 2.71, promotion speed with t-value of 2.19, remuneration growth with t-value 2.41, performance appraisal (PA) with t-value of 1.95, which indicates partial mediation and significant except Salary (SA) which become insignificant and week after including organizational commitment as mediator on the relationship between salary and turnover intention.

\subsection{Predictive Relevance of the Model}

This study further uses the blindfolding procedure to test the predictive relevance of the model. Blindfolding procedure was undertaken to assess the predictive capacity of the model. Predictive relevance is denoted by Q2. According to Hair et al. (2014) Q value is obtained by using the blindfolding to assess the parameter estimates and also assess how values are built around the model. The results were retrieved from the blindfolding output of PLS through the variable score out of which cross validated redundancy extracted. These cross validated redundancy analyzes the capacity of the model to predict the endogenous variables and also explains the quality of the model. Table 7 shows the construct cross validated redundancy. The Table 7 shows that in column four (4), Q2 shows the predictive relevance of 0.23 for the TI (Turnover intention) and 0.188 for OC (organizational commitment) which shows that this model have predictive relevance.

Table 7

Result of predictive Relevance of the Model

\begin{tabular}{rrrc}
\hline Total & SSO & SSE & 1-SSE/SSO \\
\hline OC & 1510 & 1225.024 & 0.1887 \\
TI & 1510 & 1160.662 & 0.2313 \\
\hline
\end{tabular}

\section{Discussion and Conclusion}

In general the first main purpose of this study was to examine the relationships between human resource development factors such as salary, performance appraisal, training and development and the four dimensions of career growth with employees' turnover intention. The results of the statistical analysis provide some evidences that two human resource development factors e.g. salary and performance appraisal influenced on turnover intention except training \& development. Other than that, out of four dimensions of career growth, only promotion speed and remuneration growth had significant relationships with turnover intention. Hence, human resource development and career related factors had some bearing on employees' decisions to leave their organizations, and these factors must be examined more closely.

Hence, based on statistical result, this paper concluded that if employees perceived higher salaries, fair and just appraisal system and high career growth within the organizations, they become positively attached with organization and chances to quit the organization could be reduced. So, it is the strong support from the findings of this study that salary, performance appraisal and career management 
practices such as career growth absolutely influence on turnover intention. It also indicates that failure to implement these factors might be one of the reasons organizations were not much more successful in reducing employee turnover.

Unfortunately, in terms of human resource development factor, the finding of current study indicated that training and development did not have a significant impact on turnover intention and organizational commitment which was in contrast to some previous researches which showed that training and development had a significant, negative effect on turnover intention and significant, positive effect on organizational commitment of employees. Hence, there are some studies which support the finding of current study, which claimed that training and development had no significant effect on employee turnover intention as well as organizational commitment for example, Verhees, (2012) which implies that training could also lead to more turnover intentions because better skilled employees are more employable in other institutions. Likewise, in relation to career growth dimensions, the findings of this paper show that goal progress, and professional ability development did not have a significant impact on turnover intention and organizational commitment. It would be expected that if the organization has provided an employee with a good or high position within that organization (i.e. an indicator of career progression), one would be loyal to that organization and have less intention to leave. The finding of this study does not confirm this premise. It seemed that even though one has already been given a promotion, if one is offered a better position in another organization, it is not known whether he/she will stay or leave the organization. Providing employees with the opportunity to develop their abilities also cannot guarantee that they would have less intention to leave the organization.

After direct relationship, another objective of this study is to analyze the mediating role of organizational commitment in the relationship between salary, performance appraisal and four dimensions of career growth (career goal progress, professional ability development, promotion speed and remuneration growth) and turnover intention.

In testing the mediation effect of organizational commitment on the relationship between salary and faculty turnover intention, the result indicated that if faculty perceived higher, attractive and equitable internal salary system within the organization, they would become positively attached with organization and the chances for quitting the organization will be minimized. The findings of this study does align with previous studies conducted, which means that the relationship between salary and organizational commitment is reduced when organizational commitment in taken into account (Vandenberghe \& Tremblay, 2008; Kantor, 2013; Si \& Li, 2012; Rizqi, 2015 ).

Additionally, the findings also explained the importance of organizational commitment on the relationship between performance appraisal and faculty turnover intention. The result indicated the relationship between performance appraisal and faculty turnover intention was partially mediated by organizational commitment. This implies that, if faculty perceived organization following standardized, fair and effective procedures for appraising within the organization, they would be positively attached with organization and the chances of quitting the organization would be minimized. The result of this study is consistent with empirical study conducted by Rubel and Kee, (2015) who claimed that commitment of employees would have enhanced if they had found fair and well deigned performance system.

Furthermore, in testing the mediation effect of organizational commitment on the relationship between four dimensions of career growth and faculty turnover intention, the result of this study indicates that the relationship between relationship between career growth (career goal progress, promotion speed and remuneration growth) and faculty turnover has been partially mediated by organizational commitment. This implies that if faculty perceived promotion speed in the present institution is fast, probability of being promoted is high as compared with colleagues and also perceived growth in salaries, they are positively committed and attached with organization ultimately they would less likely to leave the organization. 


\section{Practical Implications}

Application of this suggested model may enlarge the managers and organizations understanding of employee retention strategy. Based on this study and past literature, salary, performance appraisal and career management practices, which includes career growth (promotion speed and remuneration growth) were found to be a good predictor of turnover intention. Thus, management focus on these factors should be high, particularly in this crucial time. Other than that, this paper indicates that career management practices are a practical part of techniques that should be viewed by managers seeking to build a committed workforce. It may be specifically beneficial in that several commitment improving techniques have been instructed toward beginners rather than longer-term employees. Career management is a practice whereby organizations provide career counseling, training, mentoring, career paths, and career planning workshops to their employees. To overcome employee turnover issue, organization should focus on career growth policies that could create psychological contract with its employees. As such, employees who expect progress and growth in their career will ultimately stay longer in the organization, which means turnover intention will become less.

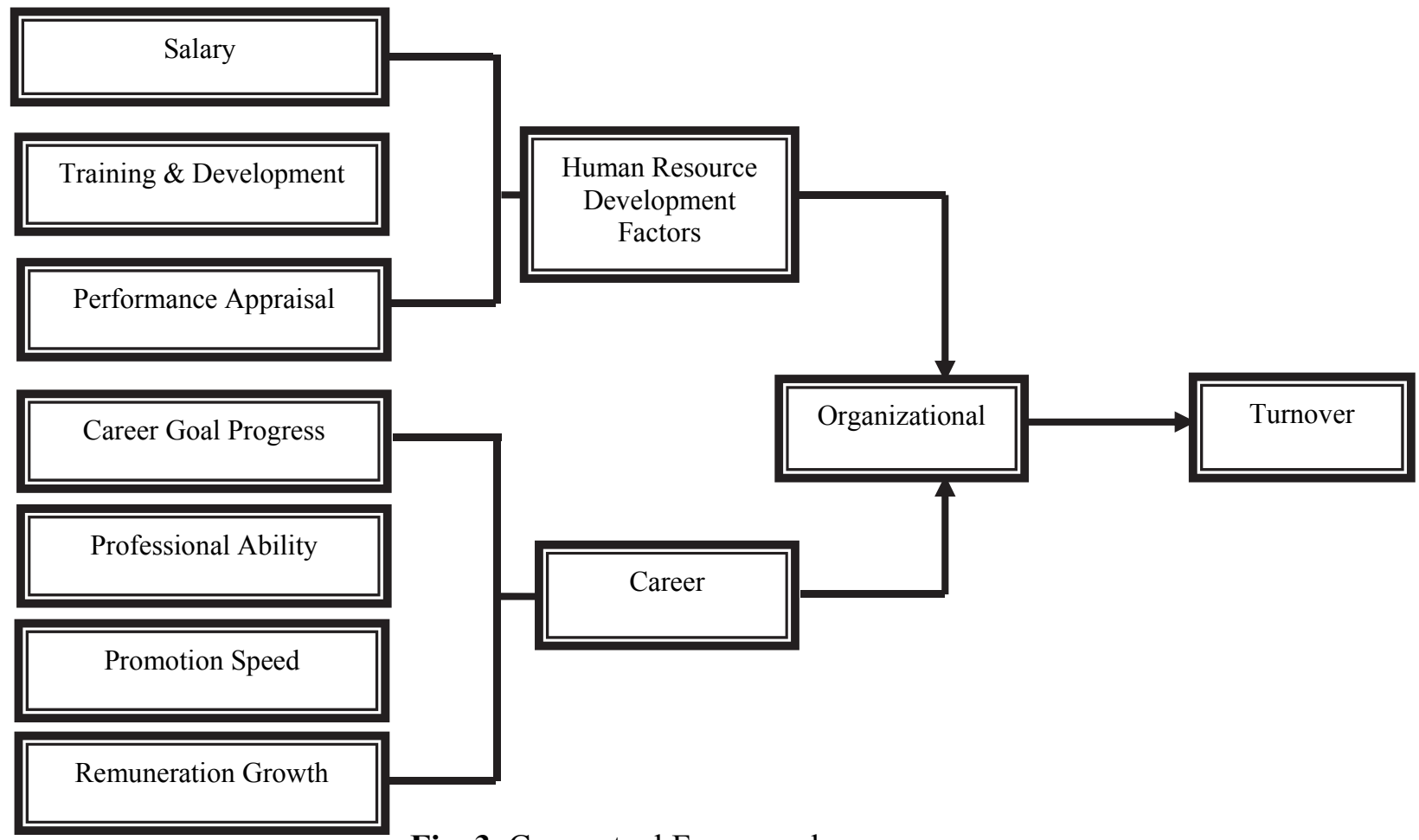

Fig. 3. Conceptual Framework

Other than that, organizations should focus and retain their best performers and also be aware of attractive job alternatives attracting to their valued employees. Organizations should focus on two issues: a retention strategy which includes pro career building and anti-career blocking which focuses on career management practices at one end and removal of career blockage on the other hand might have some effects. Further, this study provides recommendation for organization top management to introduce career development programs for accommodating employee's career needs and also provide career growth opportunities to satisfy their expectations. This argument would also increase the awareness of top management on issue regarding the career growth and Career concerns of employees regarding turnover behavior. 


\section{Limitation and Future Direction}

The statistical results of this study would be discussed in light of possible limitations. First, in this study researcher decided to include salary, performance appraisal, training and development and career management practices such as career growth. Future research should look for exploring other career management practices such as career concerns, career commitment as intervening variables that influenced the turnover intention of employees. Second, career management practices might be relevant for all employees in universities; this population includes only permanent lecturers that are reasonable sample for testing hypothesis of this study. Furthermore, this study has been taken only in one country (Pakistan) therefore, the result may not be applicable in another Asian countries.

\section{Acknowledgement}

My foremost gratitude goes to my respected supervisor, Associate Professor. Dr Faizuniah Bt Pangil, for her professional guidance and devoting his expertise to guide me to reach this level. Thank you so much. Additionally I would like to thanks to anonymous for their constructive and invaluable suggestion on earlier version of this paper.

\section{References}

Abdulkareem, R., Chauhan, A., \& Maitama, K. (2015). The relationship between human resource management practices and employee's turnover intention among registered nurses in Nigerian public hospitals : The mediating role of organisational trust. UTM Press, 2, 95-98

Al-Shuaibi, A. S. I., Shamsudin, F. M., \& Subramaniam, C. (2013). Do human resource management practices matter in reducing cyberloafing at work: Evidence from Jordan. In WEI International Academic Conference Proceedings, Istanbul, Turkey.

Allen, N.J., \& Meyer, J.P. (1990). The measurement and antecedents of affective, continuance and normative commitment to the organization. Journal of Occupational Psychology, 63, 1, 61-89

Amin, N. (2013). PAKISTAN EDUCATION STATISTICS 2013-14. Ismalabad. Retrieved from http://www.aepam.edu.pk/Files/EducationStatistics/PakistanEducationStatistics2013-14.pdf

Appleby, L., Morriss, R., Gask, L., Roland, M., Lewis, B., Perry, A., ... \& Davies, L. (2000). An educational intervention for front-line health professionals in the assessment and management of suicidal patients (The STORM Project). Psychological medicine, 30(04), 805-812.

A'yuninnisa, R. N. A., \& Saptoto, R. (2015). The effects of pay satisfaction and affective commitment on turnover intention. International Journal of Research Studies in Psychology, 4(2).

Aziz, J., Saif, N., ur Rehman, S., Qureshi, M. I., Khan, M. S., \& ullah Khan, F. (2013). Perception of job Performance appraisals toward Turnover intention and Job Satisfaction. Research Journal of Finance and Accounting,4(6), 260-267.

Blau, P. M. (1964). Exchange and Power in Social Life. New York, NY: Wiley.

Becker, G. S. (1962). Investment in human capital: A theoretical analysis. Journal of Political Economy, 70(5), 9-49.

Chew, J., \& Chan, C. C. A. (2008). Human resource practices, organizational commitment and intention to stay. International Journal of Manpower, 29(6), 503-522.

Cheng, Y., \& Waldenberger, F. (2013). Does training affect individuals' turnover intention? evidence from china. Journal of Chinese Human Resources Management, 4(1), 16-38.

Chang, E. (2005). Employees' overall perception of HRM effectiveness. Human Relation, 58(4), 523544.

Chin, W. W. (1998). The partial least squares approach to structural equation modeling. Modern methods for business research, 295(2), 295-336.

Chin, W. W., Marcolin, B. L., \& Newsted, P. R. (2003). A partial least squares latent variable modeling approach for measuring interaction effects: Results from a Monte Carlo simulation study and an electronic-mail emotion/adoption study. Information Systems Research, 14(2), 189-217.

Cohen, J. (1988). Statistical power analysis: A computer program. Routledge. 
Chun, C., \& Wang, Y. (1995). A framework for understanding differences in labor turnover and human capital investment. Journal of Economic Behavior \& Organization, 28(1), 91-105.

Cotton, J. L., \& Tuttle, J. M. (1986). Employee turnover: A meta-analysis and review with implications for research. The Academy of Management Review, 11(1), 55-70.

Dardar, A. H. A., Jusoh, A., \& Rasli, A. (2012). The impact of job training, job satisfaction and alternative job opportunities on job turnover in Libyan oil companies. Procedia - Social and Behavioral Sciences, 40, 389-394.

Delery, J. E., \& Doty, D. H. (1996). Modes in theorizing in strategic HRM: tests of universalistic, contingencies, and configurationally performance predictions. Academy of Management Journal, $39,802-835$.

Dessler, G. (2009). A framework for human resource management. Pearson Education India.

Egan, T. M., Yang, B., \& Bartlett, K. R. (2004). The effects of organizational learning culture and job satisfaction on motivation to transfer learning and turnover intention. Human Resource Development Quarterly, 15(3), 279-301.

Eisenberger, R., Armeli, S., Rexwinkel, B., Lynch, P. D., \& Rhoades, L. (2001). Reciprocation of perceived organizational support. Journal of applied psychology, 86(1), 42.

Fornell, C., \& Larcker, D. F. (1981). Evaluating structural equation models with unobservable variables and measurement error. Journal of marketing research, 18(1), 39-50.

Farrell, D., \& Stamm, C. L. (1988). Meta-analysis of the correlates of employee absence. Human Relations, 41(3), 211-227.

F. Hair Jr, J., Sarstedt, M., Hopkins, L., \& G. Kuppelwieser, V. (2014). Partial least squares structural equation modeling (PLS-SEM) An emerging tool in business research. European Business Review, 26(2), 106-121.

Grace, D. H., \& Khalsa, S. A. (2003). Re-recruiting faculty and staff: The antidote to today's high attrition. Independent School, 62(3), 20-27.

George, D. (2003). SPSS for windows step by step: A simple study guide and reference, 17.0 update, 10/e. Pearson Education India.

Giauque, D., Resenterra, F., \& Siggen, M. (2010). The relationship between HRM practices and organizational commitment of knowledge workers. Facts obtained from Swiss SMEs. Human Resource Development International,13(2), 185-205.

Guan, Y., Zhou, W., Ye, L., Jiang, P., \& Zhou, Y. (2015). Perceived organizational career management and career adaptability as predictors of success and turnover intention among Chinese employees. Journal of Vocational Behavior, 88, 230-237.

Gould-Williams, J., \& Davies, F. (2005). Using social exchange theory to predict the effects of HRM practice on employee outcomes: An analysis of public sector workers. Public Management Review, 7(1), 1-24.

Hinkin, T. R. (1995). A review of scale development practices in the study of organizations. Journal of management, 21(5), 967-988.

Hess, N., Jepsen, D. M., \& Dries, N. (2012). Career and employer change in the age of the 'boundaryless' career. Journal of Vocational Behavior, 81(2), 280-288.

Hair, J. F., Ringle, C. M., \& Sarstedt, M. (2011). PLS-SEM: Indeed a silver bullet. Journal of Marketing Theory and Practice, 19(2), 139-152.

Hair, J., Hufit, G. T. M., Ringle, C. M., \& Sarstedt, M. (2014). Partial Least Square Structural Equation. SAGE Publications.

Hair, J. F., Black, W. C., Babin, B. J., Anderson, R. E., \& Tatham, R. L. (2006). Multivariate data analysis (Vol. 6). Upper Saddle River, NJ: Pearson Prentice Hall.Hayes, A. F. (2009). Beyond Baron and Kenny: Statistical mediation analysis in the new millennium. Communication Monographs, 76(4), 408-420.

Henseler, J., Ringle, C. M., \& Sinkovics, R. R. (2009). The use of partial least squares path modeling in international marketing. Advances in International Marketing (AIM), 20, 277-320. 
Heathfield, S.M., (2014).Top 10 reasons why employees quit their job. Retrieved August 19, 2014, from http://humanresources.about.com/od/resigning-from-your-job/a/top-10-reasons employeesquit-their-job.htm

Ikramullah, M., Shah, B., Khan, S., Hassan, F. S. U., \& Zaman, T. (2012). Purposes of Performance Appraisal System: A Perceptual Study of Civil Servants in District Dera Ismail Khan Pakistan. International Journal of Business and Management, 7(3), p142.

Jackofsky, E. F., \& Peters, L. H. (1983). The hypothesized effects of ability in the turnover process. Academy of Management Review, 8(1), 46-49.

Juhdi, N., Pa'wan, F., \& Hansaram, R. M. K. (2013). HR Practices and Turnover intention: The mediating roles of organizational commitment and organizational engagement in a selected region in Malaysia. The International Journal of Human Resource Management, 24(15), 3002-3019.

Kantor, R. L. (2013). Pay satisfaction, organisational commitment, voluntary turnover intention, and attitudes to money in a South African context(Doctoral dissertation).

Karavardar, G. (2014). Organizational Career Growth and Turnover Intention: An Application in Audit Firms in Turkey. International Business Research, 7(9), p67.

Kadiresan, V., Selamat, M. H., Selladurai, S., SPR, C. R., \& Mohamed, R. K. M. H. (2015). Performance Appraisal and Training and Development of Human Resource Management Practices (HRM) on Organizational Commitment and Turnover Intention. Asian Social Science, 11(24), 162.

Khan, M. S., Khan, I., Kundi, G. M., Yar, N. B., \& Saif, N. (2014). The impact of Demography on Intention to Leave among the Academicians in the Public and Private sectors Universities of Khyber Pakhtunkhwa, Pakistan. Industrial Engineering Letters, 4(3), 1-10.

Kim, S. (2005). Factors affecting state government information technology employee turnover intentions. The American Review of Public Administration,35(2), 137-156.

Kim, S. W., Price, J. L., Mueller, C. W., \& Watson, T. W. (1996). The determinants of career intent among physicians at a US Air Force hospital.Human Relations, 49(7), 947-976.

Kroon, B., \& Freese, C. (2013). Can HR practices retain flexworkers with their agency?. International Journal of Manpower, 34(8), 899-917.

Lee, C. C., Huang, S. H., \& Zhao, C. Y. (2012). A study on factors affecting turnover intention of hotel empolyees. Asian Economic and Financial Review,2(7), 866-875.

Levine, D. I. (1993). Worth waiting for? Delayed compensation, training, and turnover in the United States and Japan. Journal of Labor Economics, 11(4), 724-752.

Lau, C. M., \& Moser, A. (2008). Behavioral effects of nonfinancial performance measures: The role of procedural fairness. Behavioral Research in Accounting, 20(2), 55-71.

Liu, S. (2012). The influences of school climate and teacher compensation on teachers' turnover intention in China. Educational Psychology, 32(5), 553-569.

Long, C. S., \& Perumal, P. (2014). Examining the impact of human resource management practices on employees' turnover intention.. International Journal of Business and Society, 15(1), 111 126.

Lum, L., Kervin, J., Clark, K., Reid, F., \& Sirola, W. (1998). Explaining nursing turnover intent: job satisfaction, pay satisfaction, or organizational commitment?. Journal of Organizational Behavior, 19(3), 305-320.

Malik, M. E., Nawab, S., Naeem, B., \& Danish, R. Q. (2010). Job satisfaction and organizational commitment of university teachers in public sector of Pakistan. International Journal of Business and Management, 5(6), p17.

Maertz, C. P., \& Campion, M. A. (1998). 25 years of voluntary turnover research: a review and critique.

Martin, T. N., Price, J. L., \& Mueller, C. W. (1981). Job performance and turnover. Journal of Applied Psychology, 66(1), 116.

Martin, C. (2003). Explaining labour turnover: Empirical evidence from UK establishments. Labour, 17(3), 391-412.

McELROY, J. C. (2001). Managing workplace commitment by putting people first. Human Resource Management Review, 11(3), 327-335. 
Mincer, J. (1962). On-the-job training: Costs, returns, and some implications.The Journal of Political Economy, 50-79.

Mincer, J. (1988). Job training, wage growth, and labor turnover (No. w2690). National Bureau of Economic Research.

Morrow, J. R. (2011). Measurement and evaluation in human performance. Human Kinetics.

Monama, T. E. T. (2015). The relationship between management style and turnover intention (Doctoral dissertation).

Mustapha, M., \& Daud, N. (2013). Perceived performance appraisal effectiveness and turnover intention of knowledge workers: A conceptual model:. Interdisciplinary Journal of Contemporary Research In Business, 5(7), 11.

Mubarak, R. Z., Wahab, Z., \& Khan, N. R. (2012). Faculty retention in higher education institutions of Pakistan. Journal of Theories and Research in Education, 7(2), 65-78.

Nouri, H., \& Parker, R. J. (2013). Career growth opportunities and employee turnover intentions in public accounting firms. The British Accounting Review,45(2), 138-148.

O'Reilly, C. A., Chatman, J., \& Caldwell, D. F. (1991). People and organizational culture: A profile comparison approach to assessing person-organization fit. Academy of Management Journal, 34(3), 487-516.

Ovadje, F. (2009). Exploring turnover among middle managers in a non-western context. International Journal of Business Research, 10(2), 64-80.

Preacher, K. J., \& Hayes, A. F. (2004). SPSS and SAS procedures for estimating indirect effects in simple mediation models. Behavior Research Methods, Instruments, \& Computers, 36(4), 717 731.

Preacher, K. J., \& Hayes, A. F. (2008). Asymptotic and resampling strategies for assessing and comparing indirect effects in multiple mediator models.Behavior Research Methods, 40(3), 879891.

Pirzada, D. S., Hayat, F., Ikram, A. A., Ayub, M., \& Waheed, K. (2013). Impact of human resources management practices on turnover, productivity and corporate financial performance. European Journal of Business and Management, 5(10), 163-176.

Poon, J. M. (2004). Effects of performance appraisal politics on job satisfaction and turnover intention. Personnel Review, 33(3), 322-334.

Porter, L. W., Steers, R. M., Mowday, R. T., \& Boulian, P. V. (1974). Organizational commitment, job satisfaction, and turnover among psychiatric technicians. Journal of applied psychology, 59(5), 603.

Price, J. L. (2001). Reflections on the determinants of voluntary turnover.International Journal of Manpower, 22(7), 600-624.

Rubel, M. R. B., \& Kee, D. M. H. (2015). Perceived Fairness of Performance Appraisal, Promotion Opportunity and Nurses Turnover Intention: The Role of Organizational Commitment. Asian Social Science, 11(9), p183.

Raihan, J. M. H. (2012). Mediating Effects of Organizational Commitment and Perceived Organizational Support on HRM Practices and Turnover Intention: A Study of Private Universities in Bangladesh (Doctoral dissertation, Universiti Utara Malaysia).

Ringle, C. M., Wende, S., \& Will, A. (2005). SmartPLS 2.0 (software).SmartPLS, Hamburg, available at: www. smartpls. de (accessed January 7, 2014).

Rosser, V. J. (2004). Faculty members' intentions to leave: A national study on their worklife and satisfaction. Research in Higher Education, 45(3), 285-309.

Sattar, S., \& Ahmed, S. (2014). Factors effecting employee turnover in banking sector. Developing Country Studies, 4(3), 110-115.

Salleh, M., Amin, A., Muda, S., \& Halim, M. A. S. A. (2013). Fairness of performance appraisal and organizational commitment. Asian Social Science, 9(2), p121.

Samuel, M. O., \& Chipunza, C. (2009). Employee retention and turnover: Using motivational variables as a panacea. African Journal of Business Management, 3(8), 410-415. 
Si, S., \& Li, Y. (2012). Human resource management practices on exit, voice, loyalty, and neglect: organizational commitment as a mediator. The International Journal of Human Resource Management, 23(8), 1705-1716.

Sekaran, U. (2006). Research methods for business: A skill building approach. John Wiley \& Sons.

Schnake, M. E., Williams, R. J., \& Fredenberger, W. (2007). Relationships between frequency of use of career management practices and employee attitudes, intention to turnover, and job search behavior. Journal of Organizational Culture, Communication and Conflict, 11(1), 53.

Shahzad, K., Bashir, S., \& Ramay, M. I. (2008). Impact of HR practices on perceived performance of university teachers in Pakistan. International review of business research papers, 4(2), 302-315.

Teclemichael Tessema, M., \& Soeters, J. L. (2006). Challenges and prospects of HRM in developing countries: testing the HRM-performance link in the Eritrean civil service. The International Journal of Human Resource Management, 17(1), 86-105.

Vandenberghe, C., \& Tremblay, M. (2008). The role of pay satisfaction and organizational commitment in turnover intentions: A two-sample study.Journal of Business and psychology, 22(3), 275-286.

Verhees, J. M. A. The Relationship Between Training and Employees' Turnover Intentions and the Role of Organizational Commitment.

Callaghan, W., Wilson, B., Ringle, C. M., \& Henseler, J. (2007). Exploring Causal Path Directionality for a Marketing Model: Using Cohen's Path Method.

Wayne, S. J., Shore, L. M., \& Liden, R. C. (1997). Perceived organizational support and leader-member exchange: A social exchange perspective.Academy of Management journal, 40(1), 82-111.

Weng, Q. X., \& Hu, B. (2009). The structure of career growth and its impact on employees' turnover intention. Industrial Engineering and Management,14(1), 14-21.

Weng, Q., \& McElroy, J. C. (2012). Organizational career growth, affective occupational commitment and turnover intentions. Journal of Vocational Behavior, 80(2), 256-265.

www.worldfactbook.com. (2013). The world fact book. Retrieved March 29, 2014, from http://medcontent.metapress.com.

Yean, T. F., \& Yahya, K. K. (2013). The influence of human resource management practices and career strategy on career satisfaction of insurance agents. International Journal of Business and Society, 14(2), 193-206.

Yusoff, R. M., \& Khan, F. (2013). Stress and Burnout in the Higher Education Sector in Pakistan : A Systematic Review of Literature. Research Journal of Recent Sciences, 2(11), 90-98

Zhao, X., Lynch, J. G., \& Chen, Q. (2010). Reconsidering Baron and Kenny: Myths and truths about mediation analysis. Journal of Consumer Research,37(2), 197-206.

Zhazykpayeva, S. (2011). The Interplay between Voluntary Labor Turnover and Performance Appraisal in Project-Based Organizations.

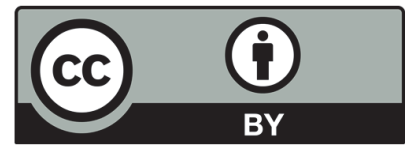

(C) 2016 by the authors; licensee Growing Science, Canada. This is an open access article distributed under the terms and conditions of the Creative Commons Attribution (CC-BY) license (http://creativecommons.org/licenses/by/4.0/). 